\title{
Abundance and diversity of soil nematodes as influenced by different types of organic manure
}

\author{
C. $\mathrm{HU}^{1}$, Y. C. $\mathrm{QI}^{2}, *$ \\ ${ }^{1}$ Institute of Plant Protection and Soil Science, Hubei Academy of Agricultural Sciences, Wuhan 430064, P. R. China, \\ E-mail: huchenghxz@163.com; ${ }^{2, *}$ College of Life Science and Technology, Huazhong Agricultural University, Wuhan \\ 430070, P. R. China, E-mail: qiych@yahoo.com.cn
}

\begin{abstract}
Summary
Nematode abundance and diversity from different types of organic manure soil treatments were investigated in a longterm field experiment carried out in Qu-Zhou experimental station, China Agricultural University. The composts used in the experiment were a traditional compost (C) $(60 \%$ straw, $30 \%$ livestock dung, $5 \%$ cottonseed-pressed trash and $5 \%$ brans), traditional compost and chicken dung compost (60\% straw, $30 \%$ chiken dung, $5 \%$ cottonseedpressed trash and $5 \%$ brans) added with effective microorganisms, EMC and EMCDC respectively. Six treatments were arranged according to a randomized block design with three replicates per treatment. Treatments were incorporation into the soil of compost EMC, EMCDC, and C each at the rates of 7.5 and $15 \mathrm{t} / \mathrm{ha}$. Plots were sown with winter wheat (Triticum aestivum L.) and summer maize (Zea mays L.) every year from 1997 to 2004. Overall, 28 nematode genera were found. Seven genera were bacterivores, 3 genera were fungivores, 13 genera were plantparasites and 5 genera were omnivores-predators. The Rhabditis, Cephalobus, Helicotylenchus were dominant genera in the present study. The bacterivores and plantparasitic nematodes were the dominant trophic groups except in $\mathrm{C}$ treatment. Nematode abundance per $100 \mathrm{~g}$ dried soil ranged from 372 to 553. Addition of effective microorganism increased the number and proportion of bacterivorous nematodes and decreased the number and proportion of plant-parasitic nematodes compared to traditional compost $\mathrm{C}$. Total number of nematode was significantly influenced by compost amount, but didn't significantly influence by EM agent. Total abundance of nematode was positively correlated with the content of soil organic matter, total $\mathrm{N}$, available $\mathrm{P}$ and $\mathrm{K}$. The long-term addition of EM agent hasn't adverse effect on soil nematode community.
\end{abstract}

Keywords: effective microorganism; organic manure; soil nematodes; biodiversity

\section{Introduction}

The increasing demand of food supply following the increase of population in developing countries requires and needs a sustainable utilization of soil. However, the maintenance of costant levels of crop production or their increase is impossible without the use of soil fertilizers (Dik, 1992; Raun \& Johnson, 1999). Long-term and large number of soil inorganic fertilizer applications can affect negatively soil fertility, soil biodiversity and crop products quality (Porazinska et al., 1999, Gruzdeva et al., 2007). So, considering the increasing importance of organic agriculture, soil organic manure applications are desirable and recommended. The effect deriving from organic manure applications includes numerous benefits resulting in an improvement of physical and chemical soil properties, i.e. porosity, aggregates stability, water exchange, fertility (Tester, 1990). Organic manure is an important source of nitrogen, phosphorus, calcium, and micro- elements such as zinc, copper, magnesium, which are essential to plant growth. Also, the incorporation of organic manure into the soil increases soil biological activity (Debosz et al., 1999). Moreover, soil amendment with different types of organic manures caused a significant reduction of populations of plant parasitic nematodes, reduced nematode damages, improved plant yields and supported the beneficial freeliving nematodes (Sasanelli, 1994; Akhtar, 1999; McSorley et al., 1999; Sasanelli et al., 2002; Arancon et al., 2003; D'Addabbo et al., 2003; Sasanelli et al., 2006; Renčo et al., 2007). Soil microorganisms play an important role in the cycle of nutrients and their activity strongly influences either plant growth or soil matter decomposition (Spedding et al., 2004). Presence or addition of different useful microorganisms in the soil, called "effective microorganisms" (EM) as reported by $\mathrm{Ni}$ and $\mathrm{Li}$ (1998), could enhance nutrient elements availability. Therefore, the addition of EM to the traditional soil organic amendments could result in a positive synergic effect. Nematodes, abundant and ubiquitous in the soil are charac- 
terised by several trophic behaviour and respond readily to environmental changes thus playing an important role in soil food web (Neher, 2001; Sánchez-Moreno et al., 2006). In this system different groups of trophic nematodes are closely correlated with other soil organisms whose activities affect primary production, soil matter decomposition, energy flows, cycle of nutrients, especially nitrogen and phosphorus cycles (Sochová et al., 2006). So, the variations of the nematofauna could provide important and useful information on soil health and quality (Urzelai et al., 2000). Soil nematode community could be considered as a bioindicator of soil perturbations including chemical, physical and agricultural effects on ecosystem health and its functioning (Sánchez-Moreno et al., 2009). The indicators include trophic group abundances and their ratios (Wasilewska, 1998), diversity indices (Urzelai et al., 2000) and soil food web indices (Ferris et al., 2001).

Some studies indicated that nematode abundance and diversity were influenced by application of organic and inorganic fertilizers (Forge et al., 2005; Wang et al., 2006; Okada \& Harada, 2007; Liang et al., 2008). Bulluck et al. (2002) and Forge et al. (2005) reported that populations of bacterivorous nematodes, mainly Rhabditidae and Cephalobidae, and fungivorous nematodes were greater in soils amended with manure than that in soils amended with chemical fertilizer. In some field experiments, Wang et al. (2006) and Okada and Harada (2007) observed that total nematode number and bacterivorous, fungivorous and omnivorous nematodes increased in conventional tillage system with chemical and organic fertilization of the plots in comparison to non amended plots. Few investigations have been undertaken on the effect of long-term application of organic manure on soil nematode populations (Liang et al. 2008). Therefore, a field experiment was conducted on wheat to assess the effect of long-term application of three different biological composts on soil nematode communities.

\section{Materials and methods}

The composts used were: traditional composted of $60 \%$ straw, $30 \%$ livestock dung, $5 \%$ cottonseed-pressed trash and $5 \%$ brans (C), traditional compost added with $200 \mathrm{ml}$ aqueous solution of effective microorganism agents (EM) per $50 \mathrm{~kg}$ compost, according to the treatments (EMC) and chiken dung compost consisting of $60 \%$ straw, $30 \%$ EM chicken dung, $5 \%$ cottonseed-pressed trash and $5 \%$ brans (EMCDC). Red sugar at dose of $1 \mathrm{~kg}$ was also added every $50 \mathrm{~kg}$ of both composts. Effective microorganism (EM) consisting of more 80 kinds of mixed and incubated microbes including photosynthetic microbes, acetate bacillus, actinomycetes, lactobacillus, microzyme (biological product for solids reduction and odor control of animal wastes), etc. as indicated by $\mathrm{Ni}$ and $\mathrm{Li}$ (1998). Effective microorganism agents were prepeared as a commercial formulation in Beijing by Yiaimu Biotechnology Company.

The field experiment was set up in 1997 at the Qu-Zhou experimental station $\left(36^{\circ} 52^{\prime} \mathrm{N}\right.$ and $\left.115^{\circ} 01^{\prime} \mathrm{E}\right)$, China Agricultural University, Hebei province, Northern China. The station is in a continental temperate monsoon zone and the climate in the region is warm, sub-humid and consists of summer rainfall and dry-cold winters.

Six treatments were arranged according to a randomized block design with three replicates per treatment. Plots $(4 \mathrm{~m}$ x $8 \mathrm{~m}$ ) were sown with winter wheat (Triticum aestivum L.) and summer maize (Zea mays L.) every year from 1997 to 2004. Treatments (Table $1-3$ ) were: incorporation into the soil of compost added with EM (EMC), chicken dung compost added with EM (EMCDC) and traditional compost (C), each at the rates of 7.5 and $15 \mathrm{t} / \mathrm{ha}$. Plots were treated every year, before sowing.

Soil samples, each consisting of fifteen cores $(2.5 \mathrm{~cm}$ diameter $\mathrm{x} 20 \mathrm{~cm}$ deep), were collected from the upper soil layer $(0-20 \mathrm{~cm})$ in June 2004 before sowing summer maize. Soil samples were put in plastic bags tightly closed to prevent moisture loss and stored in a refrigerator at a $4{ }^{\circ} \mathrm{C}$ until biological and chemical analyses. Then, root fragments and other organic debris were removed from each sample and the soil was thoroughly mixed before assessing soil moisture content and extracting free-living soil nematodes.

Soil moisture in each sample was gravimetrically determined by weight loss at $105{ }^{\circ} \mathrm{C}$ for $24 \mathrm{~h}$ and expressed as percent dry weight. Soil sub-samples were air-dried for 14 days at room temperature, and used to test alkaline hydrolysable $\mathrm{N}$ content, available $\mathrm{P}$ and $\mathrm{K}$, organic matter, total $\mathrm{N}$ and soil $\mathrm{pH}$. The potassium dichromate external heating method (Blakermore et al., 1972), the semi-micro Kjeldahl method (Bremner, 1996), the alkaline hydrolysable diffusion method (ISSCAS, 1978), the classical Olsen method (Blakermore et al., 1972) and the ammonium acetate flame photometry method ( $\mathrm{Lu}, 1999)$ were used to determined

Table 1. Soil chemical properties in different fertilizer systems

\begin{tabular}{|c|c|c|c|c|c|c|}
\hline \multirow{2}{*}{ Treatment } & EMC & EMCDC & $\mathrm{C}$ & EMC & EMCDC & $\mathrm{C}$ \\
\hline & & (15 t/ha) & & \multicolumn{3}{|c|}{ (7.5 t/ha) } \\
\hline $\mathrm{pH}$ & $7.16^{*} \mathrm{a}^{* *}$ & $7.16 \mathrm{a}$ & $7.17 \mathrm{a}$ & $7.18 \mathrm{a}$ & $7.18 \mathrm{a}$ & $7.20 \mathrm{a}$ \\
\hline Organic matter $(\mathrm{g} / \mathrm{kg})$ & $22.43 \mathrm{a}$ & $22.50 \mathrm{a}$ & $22.35 \mathrm{a}$ & $19.31 b$ & $19.57 b$ & $19.23 b$ \\
\hline Total N $(\mathrm{g} / \mathrm{kg})$ & $1.46 \mathrm{a}$ & $1.46 \mathrm{a}$ & $1.38 \mathrm{ab}$ & $1.13 \mathrm{c}$ & $1.20 \mathrm{bc}$ & $1.09 \mathrm{c}$ \\
\hline Alkali N (mg/kg) & $129.52 \mathrm{a}$ & $118.50 \mathrm{ab}$ & $110.60 \mathrm{abc}$ & $102.96 \mathrm{bc}$ & $104.08 \mathrm{bc}$ & $99.07 \mathrm{c}$ \\
\hline Available P (mg/kg) & $59.99 a$ & $60.48 \mathrm{a}$ & $54.92 \mathrm{a}$ & $31.00 \mathrm{~b}$ & $34.85 \mathrm{~b}$ & $24.66 \mathrm{~b}$ \\
\hline Available K (mg/kg) & $256.02 \mathrm{a}$ & $270.06 \mathrm{a}$ & $278.08 \mathrm{a}$ & $173.79 b$ & $181.81 \mathrm{~b}$ & $171.11 \mathrm{~b}$ \\
\hline
\end{tabular}

EMC = Compost added with effective microorganisms; EMCDC $=$ Chiken dung compost added with effective microorganisms; $\mathrm{C}=$ Traditional compost; * Average of three replicates; ** Data flanked in each row by the same letters are not significantly different according to LSD's Test $(\mathrm{P}=0.05)$. 
organic matter, total $\mathrm{N}$, alkaline hydrolysable $\mathrm{N}$, available $\mathrm{P}$ and $\mathrm{K}$, respectively. Soil $\mathrm{pH}$ was measured in $0.01 \mathrm{molL}^{-1}$ $\mathrm{CaCl}_{2}$ slurry (soil : solution $=1: 2.5$ ) using a glass electrode.

Nematode populations were extracted from $100 \mathrm{~g}$ composite fresh soil samples using the sugar flotation and centrifugation method (Barker et al., 1985). The recovered nematodes were counted and preserved in a formalin aque- ous solution (Steinberger \& Sarig, 1993). One hundred randomly selected specimens per sample were identified, to genus level, using an inverted compound microscope (Mal \& Lyon, 1975; Ying, 1998).

The characteristics of the nematode communities were described by the following approaches: 1) absolute abundance of individuals per $100 \mathrm{~g}$ dry soil; 2) trophic behaviour: a) bacterivores $(\mathrm{BF})$; b) fungivores $(\mathrm{FF})$; c) plant

Table 2. Mean relative abundance (\%) of soil nematodes among all fertilizer systems

\begin{tabular}{|c|c|c|c|c|c|c|c|}
\hline \multirow[t]{2}{*}{ Treatment/genus } & $\begin{array}{l}\text { c-p } \\
\text { value }\end{array}$ & EMC & EMCDC & $\mathrm{C}$ & EMC & EMCDC & $\mathrm{C}$ \\
\hline & & \multicolumn{3}{|c|}{$(15 \mathrm{t} / \mathrm{ha})$} & \multicolumn{3}{|c|}{$(7.5 \mathrm{t} / \mathrm{ha})$} \\
\hline Bacterivores & & $51.21^{*}$ & 56.06 & 46.07 & 59.56 & 58.49 & 39.48 \\
\hline Cephalobus & 2 & 10.56 & 15.10 & 15.07 & 11.04 & 8.11 & 4.05 \\
\hline Eucephalobus & 2 & 3.25 & 1.01 & 0.49 & 2.68 & 1.69 & 1.42 \\
\hline Cervidellus & 2 & 1.28 & 0.00 & 0.00 & 0.50 & 0.00 & 0.00 \\
\hline Acrobeles & 2 & 1.86 & 2.76 & 3.60 & 5.14 & 1.31 & 0.71 \\
\hline Protorhabditis & 1 & 4.64 & 5.53 & 1.13 & 2.55 & 6.30 & 1.99 \\
\hline Rhabditis & 1 & 29.61 & 30.49 & 23.81 & 36.56 & 40.44 & 30.01 \\
\hline Plectus & 2 & 0.00 & 1.17 & 1.98 & 1.09 & 0.65 & 1.29 \\
\hline Plant-parasites & & 42.29 & 39.58 & 49.58 & 33.56 & 34.82 & 49.16 \\
\hline Tylenchus & 2 & 1.97 & 1.01 & 2.38 & 1.36 & 2.40 & 2.34 \\
\hline Tetylenchus & 2 & 0.00 & 1.01 & 0.00 & 0.00 & 0.00 & 1.23 \\
\hline Belonolaimus & 2 & 1.28 & 0.58 & 1.49 & 0.00 & 1.25 & 0.00 \\
\hline Tylenchorhynchus & 2 & 3.95 & 5.21 & 7.75 & 3.74 & 4.03 & 10.18 \\
\hline Pratylenchus & 3 & 3.95 & 3.19 & 6.55 & 4.54 & 3.21 & 8.66 \\
\hline Hoplolaimus & 3 & 8.92 & 13.21 & 8.01 & 10.40 & 4.38 & 6.86 \\
\hline Helicotylenchus & 3 & 16.30 & 9.41 & 11.71 & 6.52 & 14.03 & 12.81 \\
\hline Rotylenchus & 3 & 4.53 & 2.18 & 7.35 & 3.55 & 1.93 & 5.85 \\
\hline Paratylenchus & 2 & 0.00 & 1.52 & 0.00 & 0.00 & 0.44 & 0.00 \\
\hline Oxydirus & 5 & 0.00 & 0.00 & 1.75 & 0.00 & 0.65 & 0.00 \\
\hline Longidorus & 5 & 0.69 & 1.67 & 2.11 & 3.45 & 2.50 & 0.64 \\
\hline Xiphinema & 5 & 0.69 & 0.58 & 0.00 & 0.00 & 0.00 & 0.00 \\
\hline Trichodorus & 4 & 0.00 & 0.00 & 0.49 & 0.00 & 0.00 & 0.58 \\
\hline Fungivores & & 5.23 & 2.76 & 3.85 & 3.15 & 3.97 & 6.97 \\
\hline Ditylenchus & 2 & 0.69 & 0.00 & 0.49 & 0.00 & 0.00 & 0.00 \\
\hline Aphelenchus & 2 & 1.28 & 0.58 & 0.63 & 1.19 & 0.00 & 2.52 \\
\hline Aphelenchoides & 2 & 3.25 & 2.18 & 2.74 & 1.96 & 3.97 & 4.45 \\
\hline Omnivores-Predators & & 1.27 & 1.60 & 0.50 & 3.73 & 2.72 & 4.39 \\
\hline Dorylaimus & 4 & 0.58 & 1.59 & 0.00 & 0.00 & 0.00 & 0.64 \\
\hline Mesodorylaimus & 4 & 0.00 & 0.00 & 0.00 & 0.00 & 0.00 & 0.71 \\
\hline Enchodelus & 4 & 0.00 & 0.00 & 0.00 & 0.00 & 0.65 & 0.00 \\
\hline Eudorylaimus & 4 & 0.00 & 0.00 & 0.00 & 0.00 & 0.00 & 0.58 \\
\hline Aporcelaimus & 5 & 0.69 & 0.00 & 0.50 & 3.73 & 2.07 & 2.45 \\
\hline
\end{tabular}

$\mathrm{EMC}=$ Compost added with effective microorganisms; EMCDC $=$ Chiken dung compost added with effective microorganisms; $\mathrm{C}=$ Traditional compost; * Average of three replicates 
parasites (PP); d) omnivores-predators (OP) (Yeates et al., 1993; Pen-Mouratov et al., 2004); 3) WI, ratio of bacterivores plus fungivores to plant parasites $[(\mathrm{BF}+\mathrm{FF}) / \mathrm{PP}]$ (Wasilewska, 1994); 4) fungivores/bacterivores ratio (FF/BF) (Twinn, 1974); 5) J', evenness, J' $=\mathrm{H}^{\prime} / \ln (\mathrm{S})$, where $S$ is the number of taxa (Pielou, 1975); 6) $\lambda$, genus dominance, $\lambda=\sum p i^{2}$, where $p i$ is the proportion of individuals in the $i$-th taxon (Simpson, 1949); 7) H', Shannon index or diversity, $\mathrm{H}^{\prime}=-\sum p i(\ln p i)$, where $p i$ is the proportion of individuals in the $i$-th taxon (Shannon \& Weaver, 1949); 8) SR, species richness, $S R=(S-1) / \ln (N)$, where $S$ is the number of taxa and $\mathrm{N}$ is the number of individuals identified (Yeates \& King, 1997); 9) MI, maturity index, $\mathrm{MI}=\sum v i p i$, where $v i$ is the $\mathrm{c}-\mathrm{p}$ value for free-living nematodes assigned by Bongers (Bongers, 1990) to the $i$-th nematode genus and $p i$ is the proportion of the genus in the nematode community; 10) PPI, plant-parasitic nematodes maturity index, PPI $=\sum v i p i$, where $v i$ is the c-p value for plant parasitic nematodes assigned by Bongers (1990) to the $i$-th nematode genus and $p i$ is the proportion of the genus in the nematode community (Yeates \& Bird, 1994); 11) $\sum$ MI, modified maturity index, including plant-feeding nematodes, $\sum \mathrm{MI}=\sum$ vipi, where $v i$ is the c-p value for freeliving and plant parasitic nematodes assigned by Bongers (1990) to the $i$-th nematode genus and $p i$ is the proportion of the genus in the nematode community (Yeates, 1994). Enrichment index (EI), basal index (BI), structure index
(SI) and channel index (CI) were calculated as described by Ferris et al. (2001; 2004).

Data were also analyzed by two-way analysis of variance (ANOVA) and means compared by LSD's Test (Least Significant Difference). All statistical analyses were performed using SPSS 11.5 software package.

\section{Results, discussion and conclusions}

Soil chemical properties (Table 1) were not significantly impacted by EM agent, but soil organic matter, available P and $\mathrm{K}$ contents were significantly affected by the different amount of fertilizers.

Overall, 28 nematode genera were observed. In particular, 7 genera were bacterivores, 3 genera were fungivores, 13 genera were plant-parasites and 5 genera were omnivorespredators (Table 2). The bacterivores were the dominant trophic groups except in the traditional compost treatment. Among the different genera Rhabditis, Cephalobus and, Helicotylenchus were the most common. The number of identified taxa ranged from 17 to 21 . Among treatments, bacterivores ranged between $39.48 \%$ and $59.56 \%$, fungivores from $2.76 \%$ and $6.97 \%$, plant-parasites from $33.56 \%$ and $49.58 \%$, and omnivores-predators ranged between $0.50 \%$ and $4.39 \%$. In particular, percentages of bacterivorous nematodes were $51.21 \%, 56.06 \%, 46.07 \%$, $59.56 \%, 58.49 \%, 39.48 \%$ in $\mathrm{EMC}, \mathrm{EMCDC}$ and $\mathrm{C}$ at

Table 3. Abundances of nematode individuals per $100 \mathrm{~g}$ dry soil, trophic groups and ecological indices for nematode community in different fertilizer systems

\begin{tabular}{|c|c|c|c|c|c|c|}
\hline & EMC & EMCDC & $\mathrm{C}$ & EMC & EMCDC & $\mathrm{C}$ \\
\hline & \multicolumn{3}{|c|}{$(15 \mathrm{t} / \mathrm{ha})$} & \multicolumn{3}{|c|}{$(7.5 \mathrm{t} / \mathrm{ha})$} \\
\hline \multicolumn{7}{|c|}{$\begin{array}{l}\text { Trophic } \\
\text { groups }\end{array}$} \\
\hline $\mathrm{BF}$ & $234.09 \mathrm{a}$ & $302.37 \mathrm{a}$ & $251.91 \mathrm{a}$ & $269.79 a$ & $251.83 \mathrm{a}$ & $145.87 \mathrm{~b}$ \\
\hline PP & $193.65 b$ & $211.59 \mathrm{ab}$ & $276.59 a$ & $149.62 b$ & $146.43 b$ & $183.34 b$ \\
\hline $\mathrm{FF}$ & $23.85 \mathrm{a}$ & $15.06 \mathrm{a}$ & $21.79 \mathrm{a}$ & $13.78 \mathrm{a}$ & $16.91 \mathrm{a}$ & $25.96 \mathrm{a}$ \\
\hline OP & $5.83 \mathrm{ab}$ & $8.59 \mathrm{ab}$ & $2.54 \mathrm{~b}$ & $16.98 \mathrm{a}$ & $11.75 \mathrm{ab}$ & $16.60 \mathrm{a}$ \\
\hline TA & $457.42 b$ & $537.61 \mathrm{a}$ & $552.82 \mathrm{a}$ & $450.17 b$ & $426.92 b c$ & $371.78 \mathrm{c}$ \\
\hline \multicolumn{7}{|c|}{$\begin{array}{l}\text { Ecological } \\
\text { indices }\end{array}$} \\
\hline WI & $1.34 \mathrm{a}$ & $1.67 \mathrm{a}$ & $1.08 \mathrm{a}$ & $1.91 \mathrm{a}$ & $1.93 \mathrm{a}$ & $0.96 \mathrm{a}$ \\
\hline $\mathrm{FF} / \mathrm{BF}$ & $0.10 \mathrm{ab}$ & $0.05 b$ & $0.10 \mathrm{ab}$ & $0.06 \mathrm{~b}$ & $0.07 \mathrm{~b}$ & $0.18 \mathrm{a}$ \\
\hline H' & $2.24 \mathrm{ab}$ & $2.18 \mathrm{ab}$ & $2.26 \mathrm{a}$ & $2.13 \mathrm{ab}$ & $1.98 \mathrm{~b}$ & $2.19 \mathrm{ab}$ \\
\hline$\lambda$ & $0.16 b$ & $0.16 \mathrm{~b}$ & $0.14 b$ & $0.18 \mathrm{ab}$ & $0.22 \mathrm{a}$ & $0.16 b$ \\
\hline J' & $0.82 \mathrm{ab}$ & $0.79 \mathrm{ab}$ & $0.84 \mathrm{a}$ & $0.82 \mathrm{ab}$ & $0.77 \mathrm{~b}$ & $0.83 a$ \\
\hline SR & $2.34 \mathrm{a}$ & $2.33 \mathrm{a}$ & $2.22 \mathrm{a}$ & $2.02 \mathrm{a}$ & $2.04 \mathrm{a}$ & $2.20 \mathrm{a}$ \\
\hline MI & $1.47 \mathrm{ab}$ & $1.45 \mathrm{ab}$ & $1.53 \mathrm{ab}$ & $1.58 \mathrm{ab}$ & $1.40 \mathrm{~b}$ & $1.60 \mathrm{a}$ \\
\hline PPI & $2.90 \mathrm{a}$ & $2.93 \mathrm{a}$ & $2.91 \mathrm{a}$ & $3.06 \mathrm{a}$ & $2.94 \mathrm{a}$ & $2.75 \mathrm{a}$ \\
\hline$\sum \mathrm{MI}$ & $2.07 \mathrm{ab}$ & $2.02 \mathrm{ab}$ & $2.23 \mathrm{a}$ & $2.07 \mathrm{ab}$ & $1.94 b$ & $2.16 \mathrm{ab}$ \\
\hline EI & 85.99ab & $86.85 \mathrm{ab}$ & $80.07 \mathrm{~b}$ & 86.89ab & $92.05 \mathrm{a}$ & $90.40 \mathrm{a}$ \\
\hline BI & $13.30 \mathrm{ab}$ & $12.67 \mathrm{ab}$ & $19.57 \mathrm{a}$ & $11.72 b$ & $7.38 b$ & $8.50 \mathrm{~b}$ \\
\hline SI & $18.67 \mathrm{bc}$ & $23.33 b c$ & $7.94 \mathrm{c}$ & $46.42 \mathrm{ab}$ & $48.22 \mathrm{ab}$ & $58.41 \mathrm{a}$ \\
\hline CI & $3.88 \mathrm{ab}$ & $1.85 \mathrm{~b}$ & $4.29 \mathrm{ab}$ & $2.07 \mathrm{ab}$ & $2.21 \mathrm{ab}$ & $5.14 \mathrm{a}$ \\
\hline
\end{tabular}

$\mathrm{EMC}=$ Compost added with effective microorganisms; EMCDC $=$ Chiken dung compost added with effective microorganisms; $\mathrm{C}=$ Traditional compost $\mathrm{BF}=$ Bacterivores; $\mathrm{FF}=$ Fungivores; $\mathrm{PP}=$ Plant parasites; $\mathrm{OP}=$ Omnivores-predators; $\mathrm{TA}=$ Total nematode individuals.

Community index: $\mathrm{WI}=$ ratio of bacterivores plus fungivores to plant parasites; $\mathrm{FF} / \mathrm{BF}=$ fungivores/bacterivores ratio; $\mathrm{H}^{\prime}=\mathrm{Shannon}$ index;

$\lambda=$ genus dominance; $\mathrm{J}^{\prime}=$ evenness; $\mathrm{SR}=$ species richness; $\mathrm{MI}=$ maturity index, $\mathrm{PPI}=$ plant-parasitic maturity index; $\sum \mathrm{MI}=$ combined maturity index. including plant-parasitic nematode: $\mathrm{EI}=$ enrichment index: $\mathrm{BI}=$ basal index: $\mathrm{SI}=$ structural index: $\mathrm{CI}=\mathrm{channel}$ index. 
rates of $15 \mathrm{t} /$ ha and in EMC, EMCDC and $\mathrm{C}$ at rates of 7.5 $\mathrm{t} /$ ha, respectively (Tab. 2). For the same treatments, percentages of plant-parasitic nematode were $42.29 \%, 39.58$ $\%, 49.58 \%, 33.56 \%, 34.82 \%$, and $49.16 \%$ (Tab. 2).

The abundances of soil nematodes were significantly affected by the amount of composts, but they were not significantly influenced by EM agents (Tab. 3, Tab. 4). Bacterivorous, plant-parasitic and omnivorous and predatory nematode groups were significantly influenced by the amount of fertilization only in $\mathrm{C}$ treatment (Tab. 3). Significant EM agents effects were not found in the ratio of bacterivores plus fungivores to plant parasites, shannon index, genus dominance, evenness, species richness, maturity index, plant-parasitic nematode maturity index, modified maturity index, enrichment index, basal index, structure index and channel index. But significant compost amount effects were found in the fungivore/bacterivore ratio, genus dominance, enrichment index, basal index, and structure index (Tab. 3).

Total abundance of nematodes was positively correlated with the content of soil organic matter, total $\mathrm{N}$, available $\mathrm{P}$, and available K (Tab. 5).

The mean number of nematodes ranged between 372 and 553 individuals per $100 \mathrm{~g}$ dried soil, which is similar to results previously reported by Zolda (2006) in semi-natural steppe grasslands $(185-590)$ and by Li et al. (2007) in rice-wheat rotation ecosystem $(117-912)$. Abundances of soil nematode were increased owing to addition of EM agents, except for EMC treatment at $15 \mathrm{t} / \mathrm{ha}$.

The number of nematode genera (28) observed in this study was similar to that observed by Zhang et al. (2007) and Urzelai et al. (2000), but less than that reported for original dry meadow (56) (Zolda \& Háněl, 2007), Japanese soybean field (51) (Okada \& Harada, 2007) and long-term application of fertilizer (Liang et al., 2008).

At the lower rate of compost the addition of EM agents significantly increased bacterivorous nematodes, whereas at $15 \mathrm{t} / \mathrm{ha}$ no significant increase was observed; in this case the positive effect of EM on BF could be musked by the larger amount of organic matter of the composts. Previous investigations reported that bacterivorous nematodes were more numerous than other trophic groups in soil treated with compost than in soil receiving chemical fertilizers (Ferris \& Matute, 2003). Wang et al. (2006) found that bacterivorous nematodes were the predominant trophic group in a squash (Cucurbita pepo) agro-ecosystem and similar results were also reported by Jiang et al. (2007). However, Ou et al. (2005) found that plant parasitic nematodes were the dominant trophic group in a maize field.

In previous investigations the addition of EM agents also increased microorganism population in the soil (Tong et al., 2003a; 2003b; Wang et al., 2004; Zhou et al., 2005).

Table 4. Two-way ANOVA analysis of soil nematode indices under EM effects and compost amount effects

\begin{tabular}{|c|c|c|c|c|c|c|}
\hline & \multicolumn{2}{|c|}{ EM effects } & \multicolumn{2}{|c|}{ Compost amount effects } & \multicolumn{2}{|c|}{ Interaction } \\
\hline & $F$ & $P$ & $F$ & $P$ & $F$ & $P$ \\
\hline \multicolumn{7}{|l|}{$\begin{array}{l}\text { Trophic } \\
\text { groups }\end{array}$} \\
\hline $\mathrm{BF}$ & 4.307 & 0.039 & 3.290 & 0.095 & 3.446 & 0.066 \\
\hline FF & 1.047 & 0.381 & 0.089 & 0.770 & 0.957 & 0.412 \\
\hline PP & 3.317 & 0.071 & 11.224 & 0.006 & 0.501 & 0.618 \\
\hline $\mathrm{OP}$ & 0.120 & 0.888 & 9.234 & 0.010 & 1.095 & 0.366 \\
\hline TA & 1.228 & 0.327 & 42.816 & 0.000 & 10.981 & 0.002 \\
\hline \multicolumn{7}{|c|}{$\begin{array}{l}\text { Ecological } \\
\text { indices }\end{array}$} \\
\hline WI & 3.138 & 0.080 & 0.773 & 0.397 & 0.566 & 0.582 \\
\hline $\mathrm{FF} / \mathrm{BF}$ & 5.047 & 0.026 & 0.943 & 0.351 & 3.136 & 0.080 \\
\hline H' & 1.526 & 0.257 & 3.484 & 0.087 & 0.321 & 0.732 \\
\hline$\lambda$ & 2.880 & 0.095 & 5.607 & 0.036 & 0.827 & 0.461 \\
\hline $\mathrm{J}^{\prime}$ & 3.390 & 0.068 & 0.363 & 0.558 & 0.377 & 0.694 \\
\hline SR & 0.040 & 0.961 & 5.355 & 0.039 & 1.065 & 0.375 \\
\hline MI & 2.654 & 0.111 & 0.696 & 0.420 & 0.828 & 0.460 \\
\hline PPI & 0.981 & 0.403 & 0.002 & 0.962 & 1.029 & 0.387 \\
\hline$\sum \mathrm{MI}$ & 3.223 & 0.076 & 0.417 & 0.531 & 0.142 & 0.869 \\
\hline EI & 1.721 & 0.220 & 8.204 & 0.014 & 2.023 & 0.175 \\
\hline BI & 1.578 & 0.246 & 10.371 & 0.007 & 2.213 & 0.152 \\
\hline SI & 0.062 & 0.940 & 18.634 & 0.001 & 1.033 & 0.385 \\
\hline $\mathrm{CI}$ & 3.272 & 0.073 & 0.054 & 0.821 & 0.881 & 0.439 \\
\hline
\end{tabular}

$\mathrm{BF}=$ Bacterivores; $\mathrm{FF}=$ Fungivores; $\mathrm{PP}=$ Plant parasites; $\mathrm{OP}=$ Omnivores-predators, $\mathrm{TA}=$ Total nematode individuals.

Community index: $\mathrm{WI}=$ ratio of bacterivores plus fungivores to plant parasites; $\mathrm{FF} / \mathrm{BF}=$ fungivores/bacterivores ratio; $\mathrm{H}^{\prime}=$ Shannon index; $\lambda$ = genus dominance; $\mathrm{J}^{\prime}=$ evenness; $\mathrm{SR}=$ species richness; $\mathrm{MI}=$ maturity index, $\mathrm{PPI}=$ plant-parasitic maturity index; $\sum \mathrm{MI}=$ combined maturity index, including plant-parasitic nematode; $\mathrm{EI}=$ enrichment index; $\mathrm{BI}=$ basal index; $\mathrm{SI}=$ structural index; $\mathrm{CI}=$ channel index.

Values of $P<0.05$ were considered significantly. 
Table 5. Correlation coefficients between nematode indices and soil chemical properties

\begin{tabular}{ccccccc}
\hline & $\mathrm{pH}$ & $\begin{array}{c}\text { Organic } \\
\text { matter }\end{array}$ & Total N & Alkali N & Available P & Available K \\
\hline $\begin{array}{c}\text { Trophic } \\
\text { groups }\end{array}$ & & & & & \\
BF & -0.287 & 0.398 & 0.352 & 0.390 & $0.482^{*}$ & 0.391 \\
FF & -0.137 & -0.022 & -0.007 & -0.109 & -0.068 & 0.027 \\
PP & -0.136 & 0.367 & 0.428 & 0.174 & $0.491^{*}$ & $0.554^{*}$ \\
OP & -0.210 & $-0.511^{*}$ & -0.395 & $-0.573^{*}$ & $-0.592^{* *}$ & $-0.564^{*}$ \\
TA & -0.415 & $0.605^{* *}$ & $0.628^{* *}$ & 0.420 & $0.768^{* *}$ & $0.753^{* *}$ \\
Ecological & & & & & \\
indices & & & & & -0.035 & -0.104 \\
WI & -0.172 & 0.020 & -0.074 & 0.081 & -0.337 & -0.198 \\
F/B & 0.071 & -0.237 & -0.220 & -0.323 & 0.184 & 0.297 \\
H' & -0.036 & 0.230 & 0.217 & 0.052 & -0.189 & -0.365 \\
$\lambda$ & 0.045 & -0.301 & -0.210 & -0.069 & -0.149 & 0.009 \\
J' & 0.108 & -0.013 & -0.130 & -0.156 & 0.422 & 0.437 \\
SR & -0.160 & 0.374 & $0.517^{*}$ & 0.243 & -0.363 & -0.062 \\
MI & -0.149 & -0.039 & -0.165 & -0.428 & 0.117 & 0.047 \\
PPI & -0.218 & -0.007 & 0.158 & 0.183 & -0.009 & 0.154 \\
$\sum$ MI & -0.097 & 0.014 & 0.118 & -0.166 & -0.366 & $-0.610^{* *}$ \\
EI & 0.012 & $-0.598^{* *}$ & -0.293 & -0.179 & 0.419 & $0.643^{* *}$ \\
BI & 0.003 & $0.622^{* *}$ & 0.320 & 0.221 & $-0.684^{* *}$ & $-0.623^{* *}$ \\
SI & -0.133 & $-0.550^{*}$ & -0.431 & $-0.585^{*}$ & -0.148 & 0.035 \\
CI & 0.025 & 0.011 & -0.092 & -0.183 & -0.193 \\
\hline BF & & & & & \\
\hline
\end{tabular}

$\mathrm{BF}=$ Bacterivores; $\mathrm{FF}=$ Fungivores; $\mathrm{PP}=$ Plant parasites; $\mathrm{OP}=$ Omnivores-predators, $\mathrm{TA}=$ Total nematode individuals.

Community index: $\mathrm{WI}=$ ratio of bacterivores plus fungivores to plant parasites; $\mathrm{FF} / \mathrm{BF}=$ fungivores/bacterivores ratio; $\mathrm{H}^{\prime}=\mathrm{Shannon}$ index;

$\lambda=$ genus dominance; J' = evenness; $\mathrm{SR}=$ species richness; $\mathrm{MI}=$ maturity index, $\mathrm{PPI}=$ plant-parasitic maturity index; $\sum \mathrm{MI}=$ combined maturity index, including plant-parasitic nematode; $\mathrm{EI}=$ enrichment index; $\mathrm{BI}=$ basal index; $\mathrm{SI}=$ structural index; $\mathrm{CI}=\mathrm{channel}$ index.

* Significant at $P<0.05$ and $* *$ significant at $P<0.01$.

The decreasing effect of effective microorganism on number of plant-parasitic nematodes in comparison to traditional compost treatments could be attributed to some toxic effect of metabolites produced by EM and/or to a competition between the two groups, indicating that EM agents could play a role in the biological control of plant parasitic nematodes.

Mean WI values ranged between 0.93 and 1.67, and are comparable to the mean values observed by Liang et al. (1999) for a potato field and by Pen-Mouratov et al. (2008) in a desert communities. The $\mathrm{FF} / \mathrm{BF}$ values reflect the structure of the microflora community and indicate the status of the decomposition pathway in detrital food webs (Ruess, 2003). They ranged between 0.05 and 0.18 and were lower than that observed in desert ecosystem (PenMouratov et al., 2008), indicating a large bacterial population presence with a dominant bacterial decomposition pathway (Ruess, 2003). The $\mathrm{T}$ values $(2.06-2.45)$ observed in our study were similar to those $(2.01-2.37)$ reported by Pen-Mouratov et al. (2008) in the Northern Negev Desert, Israel.

The Shannon index (H') affords more weight to rare species, and its high value indicates greater diversity. The $\mathrm{H}^{\prime}$ values $(1.98-2.26)$ observed in this study were higher than that observed by Bulluck et al. (2002) in Goldsboro and Clinton farming systems $(0.55-1.47)$. Genus dominance $(\lambda)$ was used to assess the dominance of all nematode genera in the samples. The observed $\lambda$ values $(0.14-$ $0.22)$ were within the range $(0.09-0.70)$ observed by
McSorley \& Frederick (1996) and lower than that obtained by Pen-Mouratov et al. (2004). The J' values $(0.77-0.84)$ calculated in the field experiment were higher than results reported by Pen-Mouratov et al. (2008), whereas the species richness $(\mathrm{SR})$ values $(2.02-2.34)$ were lower than that reported by Yeates \& King (1997) (3.03).

The maturity index (MI) is a measure based on the composition of the nematode community and can reflect the degree of disturbance of the soil ecosystem (Bongers, 1990). In this study the MI values ranged from 1.40 and 1.58 and they were lower than that reported in Chinese paddy fields $(2.86$ - 3.23) (Liu et al., 2008). The lower MI values observed suggested that abundant opportunist nematodes (c $\mathrm{p}$ values $1-2$ ) were present in compost treated soil. The plant parasitic indices (PPI) ranged from 2.75 to 3.06 and $\sum$ MI values ranged from $1.94-2.23$. At $15 \mathrm{t} / \mathrm{ha}$ of the composts, plant parasitic populations were significantly decreased by the addition of EM to the traditional organic compost $\mathrm{C}$. PPI and $\sum \mathrm{MI}$ values were higher and similar to that observed in the black soil region of Northeast China by Liang et al. (2002) and by Wang et al. (2006), respectively.

In conclusion, the application of EM to organic compost could increase the number and proportion of bacterivorous nematodes, and decrease the number and proportion of plant-parasitic nematode compared to traditional compost alone. Therefore, long-term addition of EM agents could be suggested as a nematode management strategy as it provides an increase of pest suppressivity by reducing the 
impact on soil-plant equlibrium compared to chemicals and inorganic fertilizers.

\section{Acknowledgements}

This research was supported by the Key Project of the National " $10^{\text {th }}$-FiveYear-Plan" of China (Grant no. 2004BA508B01) and Key Discipline Foundation of Ecology in Beijing Municipality (Grant no. XK10019440). The authors wish to express their appreciation to anonymous reviewer for valuable comments.

\section{References}

AKHTAR, M. (1999): Plant growth and nematode dynamics in response to soil amendments with neem products, urea and compost. Bioresour. Technol., 69: 181-183

Arancon, N.Q., Galvis, P., Edwards, C., Yardim, E. (2003): The trophic diversity of nematode communities in soil treated with vermicompost. Pedobiologia, 47: 736 740

Barker, K. R., CArter, C. C., SAsser, J. N. (1985): An Advanced Treatise on Meloidogyne, Methodology, Vol. 2. North Carolina State University Graphics, Raleigh, NC, pp. 223

Blakemore, L. C., Searle, P. L., Daly, B. K. (1972): Methods for chemical analysis of soils. New Zealand Soil Bureau Report 10 A. Government Printer, Wellington.

BONGERS, T. (1990): The maturity index: an ecological measure of environmental disturbance based on nematode species composition. Oecologia, 83: $14-19$

BREMNER, J. M. (1996): Nitrogen-Total. In: SPARKS, D. L. (Ed) Methods of Soil Analysis. Part 3. Soil Science Society of America. Book Series 5, Madison, pp. 1085 - 1086 Bulluck, L. R., BARKer, K. R., Ristaino, J. B. (2002): Influences of organic and synthetic soil fertility amendments on nematode trophic groups and community dynamics under tomatoes. Appl. Soil Ecol., 21: 233 - 250

D’addabbo, T., Sasanelli, N., Lamberti, F., Greco, P., CARElla, A. (2003): Olive pomace and chicken manure amendments for control of Meloidogyne incognita over two crop cycles. Nematropica, 33: $1-7$

Debosz, K., Rasmussen, P. H., Pedersen, A. R. (1999): Temporal variations in microbial biomass $\mathrm{C}$ and cellulolytic enzyme activity in arable soils: effects of organic matter input. Appl. Soil Ecol., 13: 209 - 218

DIK, R.P. (1992): A review: long-term effects of agricultural systems on soil biochemical and microbial parameters. Agric. Ecosyst. Environ., 40: 25 - 36

Ferris, H., Bongers T., De Goede, R. G. M. (2001): A framework for soil food web diagnostics: extension of the nematode faunal analysis concept. Appl. Soil Ecol., 18: 13 $-29$

Ferris, H., Venette, R. C., Scow, K. M. (2004): Soil management to enhance bacterivore and fungivore nematode populations and their nitrogen mineralisation function. Appl. Soil Ecol., 25: 19 - 35

FerRis, H., MAtute, M. M. (2003): Structural and functional succession in the nematode fauna of a soil food web.
Appl. Soil Ecol., 23: 93 - 110

Forge, T. A., Bittman, S., Kowalenko, C. G. (2005): Responses of grassland soil nematodes and protozoa to multi-year and single-year applications of dairy manure slurry and fertilizer. Soil Biol. Biochem., 37: 1751 - 1762 Gruzdeva, L. I., Matveeva, E. M., Kovalenko, T. E. (2007): Changes in soil nematode communities under the impact of fertilizers. Eurasian Soil Sci., 40, 681 - 693

Hu, C., CAO, Z. P., LuO, Y. R., MA, Y. L. (2007): Effects of long-term application of microorganismic compost or vermicompost on soil fertility and microbial biomass carbon. Chin. J. Eco-Agric. (In Chinese), 15(3): 48 - 51

INSTITUTE OF SOIL SCIENCE, CHINESE ACADEMY OF SCIENCES (ISSCAS) (ed.). (1978). Physical-Chemical Analysis of Soil. Shanghai Science and Technology Publishing House, Shanghai. 593pp. (In Chinese)

JiAnG, D. M., Li, Q., LiU, F. M., JiAng, Y., LiAnG, W. J. (2007): Vertical distribution of soil nematodes in an age sequence of Caragana microphylla plantations in the Horqin Sandy Land, Northeast China. Ecol. Res., 22: 49 56

Li, Q., Liang, W. J., Jiang, Y., Shi, Y., Zhu, J. G., NEHER, D. A. (2007): Effect of elevated $\mathrm{CO}_{2}$ and N fertilisation on soil nematode abundance and diversity in a wheat field. Appl. Soil Ecol., 36: 63 - 69

Liang, W. J., Lavian, I., Steinberger, Y. (1999): Dynamics of nematode community composition in a potato field. Pedobiologia, 43: 459 - 469

Liang, W. J., Chen, L. J., Li, Q., Wang, P., Duan, Y. X. (2002): Responses of nematode communities to inorganic fertilizer disturbance in a farmland ecosystem. Pedosphere, 12(3): $193-200$

Liang, W. J., LOU, Y. L., Li, Q., ZhONG, S., Zhang, X. K., WANG, J. K. (2008): Nematode faunal response to long-term application of nitrogen fertilizer and organic manure in Northeast China. Soil Biol. Biochem., DOI:10.1016/j.soilbio.2008.06.018

LIU, M. Q., ChEn, X. Y., QIN, J. T., WANG, D., GRIFFITHS, B., HU, F. (2008): A sequential extraction procedure reveals that water management affects soil nematode communities in paddy fields. Appl. Soil Ecol., 40: 250 - 259

LU, R. K. (1999): Methods of Soil and Agricultural Chemistry. China Agriculture Science and Technology Press, Beijing. (In Chinese)

Mcsorley, R., Stansly, P. A., Noling, J. W., Obreza, T. A., ConNer, J. M. (1999): Impact of soil organic amendments and fumigation on plant parasitic nematodes in a southern Florida vegetable filed. Nematropica, 27: 181 189

MAL, W. F., Lyon, H. H. (1975): Pictorial key to genera of pant-parasitic nematodes. Cornell University Press. Ithaca \& London. pp. 1 - 219

McSorley, R., Frederick, J. J. (1996): Nematode community structure in rows and between rows of a soybean field. Fundam. Appl. Nematol., 19: $251-261$

Ni, Y. Z., LI, W. J. (1998): Study of EM technology application. Beijing: China Agricultural University Press, $15-$ 32 (In Chinese) 
NeHER, D. A. (2001): Role of nematodes in soil health and their use as indicators. J. Nematol., 33(4): $161-168$

OKADA, H., HARADA, H. (2007): Effects of tillage and fertilizer on nematode communities in a Japanese soybean field. Appl. Soil Ecol., 35: 582 - 598

Ou, W., Liang, W. J., Jiang, Y., Li, Q., Wen, D. Z. (2005): Vertical distribution of soil nematodes under different land use types in an aquic brown soil. Pedobiologia, 49: 139-148

Pen-Mouratov, S., Barness, G., Steinberger, Y. (2008): Effect of desert plant ecophysiological adaptation on soil nematode communities. Eur. J. Soil Biol., 44: 298 308

Pen-Mouratov, S., Rakhimbaev, M., Barness, G., STEINBERGER, Y. (2004): Spatial and temporal dynamics of nematode populations under Zygophyllum dumosum in arid environments. Eur. J. Soil Biol., 40: 31 - 46

PIELOU, E. C. (1975): Ecological diversity. New York: John Wiley, pp. 165

PoraZinsKa, D. L., DUNCAN, L. W., MCSORley, R., GrAHAM, J. H. (1999): Nematode communities as indicators of status and processes of a soil ecosystem influenced by agricultural management practices. Appl. Soil Ecol., 13: $69-86$

RAUN, W. R., JOHNSON, G. V. (1999): Improving nitrogen use efficiency for cereal production. Agron. J., 91: 357 363

RenČO, M., D'AdDABBo, T., SASANElli, N., PAPAJOVA, I. (2007): The effect of five composts of different origin on the survival and reproduction of Globodera rostochiensis. Nematology, 9(4): $537-543$

RUESS, L. (2003): Nematode soil faunal analysis of decomposition pathways in different ecosystems. Nematology, 5, $179-181$

SÁnchez-Moreno, S., Minoshima, H., Ferris, H., JACKSON, L. E. (2006): Linking soil properties and nematode community composition: effects of soil management on soil food webs. Nematology, 8: $703-715$

SÁncheZ-Moreno, S., Nicola N. L., Ferris H., ZALOM F. G. (2009): Effects of agricultural management on nematode-mite assemblages: Soil food web indices as predictors of mite community composition. Appl. Soil Ecol., 41: $107-117$

SASANELLI, N. (1994): Tables of Nematode-Pathogenicity. Nematol. Mediterr., 22: 153 - 157

SASAnelli, N., D’addabBo T., Convertini, G., Ferri, D. (2002): Soil Phytoparasitic Nematodes Suppression and Changes of Chemical Properties Determined by Waste Residues from Olive Oil Extraction. Proc. $12^{\text {th }}$ ISCO Conf., May 26-31, 2002 Beijing China. Vol. III: 588 - 592 SASANElli N., Ferri D., Convertini G., D'ADDABbo, T. (2006): Nematicidal and agronomical effects of composted olive pomace amendments. Proc. $12^{\text {th }}$ Congr. of the Mediterr. Phytopathol. Union, 11 - 15 June, 565 - 567

SHANNON, C. E., WeAVER, W. (1949): The Mathematical Theory of Communication. Urbana, IL: University of Illinois Press.

SIMPSON, E. H. (1949): Measurement of diversity. Nature,
163: 668

Sochová, I., Hofman, J., HoloubeK, I. (2006): Using nematodes in soil ecotoxicology. Environ. Int., 32: $374-$ 383

Spedding, T. A., Hamel, C., Mehuys, G. R., MADRAMOOTOO, C. A. (2004): Soil microbial dynamics in maize-growing soil under different tillage and residue management systems. Soil Biol. Biochem., 36: 499 - 512

STEINBERGER, Y., SARIG, S. (1993): Response by soil nematode populations in the soil microbial biomass to a rain episode in the hot, dry Negev Desert. Biol. Fertil. Soils, 16: $188-192$

Steinberger, Y., Liang, W. J., Savkina, E., Mesh, T., BARNESS, G. (2001): Nematode community composition and diversity associated with a topoclimatic transect in a rain shadow desert. Eur. J. Soil Biol., 37: 315 - 320

TESTER, C. F. (1990): Organic amendment effects on physical and chemical properties of a sandy soil. Soil Sci. Soc. Am. J., 65: $1284-1292$

TonG, X. J., LI, W. J., NI, Y. Z. (2003): Effects of effective microorganisms (EM) compost on summer maize growth and development. Chin. J. Eco-Agric., 11(4): $18-$ 20 (In Chinese)

TonG, X. J., LI, W. J., LI, J., NI, Y. Z. (2003): Effect of effective microorganisms compost on winter wheat growth. Res. Agric. Modernization, 24(6): 456 - 463 (In Chinese)

TwinN, D. C. (1974): Nematodes. In: Dickinson, C. H., PugH, G. J. F. (Eds) Biology of Plant Litter Decomposition. London, UK: Academic Press, pp. 421 - 465

Urzelai, A., HernándeZ, A. J., PASTOR, J. (2000): Biotic indices based on soil nematode communities for assessing soil quality in terrestrial ecosystems. Sci. Total Environ., $247,253-261$

WAng, K. H., Mcsorley, R., Marshall, A., Gallaher, R. N. (2006): Influence of organic crotalaria juncea hay and ammonium nitrate fertilizers on soil nematode communities. Appl. Soil Ecol., 31: 186 - 198

WANG, L. G., LI, W. J., QIU, J. J., MA, Y. L., WANG, Y, C. (2004): Effects of biological organic fertilizer on crops growth, soil fertility and yield. Soil and Fertil., (5): 12 - 16 (In Chinese)

WASILEWSKA, L. (1994): The effect of age of meadows on succession and diversity in soil nematode communities. Pedobiologia, 38, 1 - 11

WASILEWSKA, L. (1998): Changes in the proportions of groups of bacteriovorous soil nematodes with different life strategies in relation to environmental conditions. Appl. Soil Ecol., 9, 215 - 220

YEATES, G. W. (1994): Modification and qualification of the nematode maturity index. Pedobiologia, 38, 97-101

Yeates, G. W., Bongers, T. De Goede R. G. M., Freckman D.W., GeOrGIEVA, S. S. (1993): Feeding habits in soil nematode families and genera - an outline for ecologists. J. Nematol., 25(3): $315-331$

YeATES, G. W., KING K. L. (1997): Soil nematodes as indicators of the effect of management on grasslands in the New England Tablelands (NSW): Comparison of native 
and improved grasslands. Pedobiologia, 41, 526 - 536

YeAtES, G. W., Bird, A. F. (1994): Some observations on the influence of agricultural practices on the nematode faunae of some South Australian soils. Fundam. Appl. Nematol., 7: $133-145$

YING, W. Y. (1998): Pictorial keys to soil animals of China. Beijing: China Science Press, pp. 51 - 89 (In Chinese)

Zhang, X. K., LiAnG, W. J., JiAnG, D. M., LiU, Z. M., JIANG, S. W. (2007): Soil nematode community structure in a Chinese sand dune system. Helminthologia, 44(4): 204 $-209$

RECEIVED FEBRUARY 27, 2009
ZHOU, L. H., Ni, Y. Z., LI, W. J. (2005): Effects of longterm application of EM biological-organic fertilizer on winter wheat production. Trans. CSAE, 21(Supp): 221 224 (In Chinese)

ZoLDA, P. (2006): Nematode communities of grazed and ungrazed semi-natural steppe grasslands in Eastern Austria. Pedobiologia, 50: $11-22$

ZOLDA, P., HÁNĚL, L. (2007): Soil nematodes inhabiting an original dry meadow and an abandoned vineyard in the National Park Seewinkel, Eastern Austria. Helminthologia, 2007, 44(3): 112 - 117

ACCEPTED OCTOBER 30, 2009 